\title{
LITERATURE REVIEW: THE ROLE AND EFFECTS OF HOSPITAL HEALTH PROMOTION ON HEALTH POLITICS
}

\author{
Neula Armyttha Rizki Ramadhani \\ Department of Health Promotion and Behavioral Science \\ Faculty of Public Health, Airlangga University, Surabaya, Indonesia \\ Correspondence address: Neula Armytha R \\ Email: neulaarmyttha@gmail.com
}

\begin{abstract}
An applicable health system must be integrated with existing health facilities in the community, such as health facilities at hospitals. One of the efforts made by the hospital is hospital health promotion aimed to enable patients and their families to prevent health problems, improve health more independently, and be active in the healing process, of course while being supported by policy regulations. This study aimed to describe the implementation of hospital health promotion as a health political product that certainly affects the degree of public health. This study was a literature review. Data were collected by library research. Based on the results, making a political decision (especially in the health sector) would affect the health of the community, in addition to politics being influenced by the state of public health. The role of hospitals as health promoters could be realized through hospital health promotion with a new preventive paradigm. Moreover, health promotion could also help improve fair and equal health services while still prioritizing quality and promoting preventive and promotive efforts. More numbers of health personnel both in the curative and preventive treatment should be considered for health policymaking to improve health services, especially in hospital settings.
\end{abstract}

Keywords: health promotion in hospital, health politics

\section{INTRODUCTION}

Article 52 paragraph (1) of Law No. 36 of 2009 concerning Health states that there are 2 types of health services, namely individual and community services. Health services are promotive, preventive, curative, and rehabilitative and ensure human needs in the health sector to be fulfilled. Based on this statement, it could be seen that the fulfillment of public health requires complex steps. A part of the services is curative and rehabilitative treatment at hospitals.

To achieve optimal health, it is necessary to exploring the will, awareness, and ability of people to live healthily. Hospitals have an important role in health development and becomes an integral part of international development (Health Promotion Center of the Indonesian Ministry of Health, 2010). Hospitals function as a resource center to develop public health, and they must be integrated into a health system (Indonesian Ministry of Health, 2009). However, it is unfortunate that most hospitals in Indonesia still emphasize their services on curative and rehabilitative aspects. Therefore, it causes inconsistency in hospital functions making it shift into an elite facility that is independent from the reference to the health system in an area.

The World Health Organization (WHO) is aware of the importance of implementing health promotion at hospitals; thus, immediate actions for implementing it are required. The absence of world standards regarding hospital health promotion was an issue in the last years. As a result, the WHO held the 9th Hospital Health Promotion Conference in Copenhagen in May 2001, which resulted in the formation of work group for designing global hospital health promotion standards.

After the conference took place, the working group (assisted by several 
countries of the WHO's working network) sparked hospital health promotion standards, with 5 core standard points applied to hospitals around the world. The five standards included (1) the existance of management policy related to hospital health promotion prior to implementation; (2) health promotion assessment prior to implementation; (3) home interventions of health promotion; (4) environmental health promotion for all hospital employees; and (5) partnership building with related stakeholders (WHO, 2004).

As stated in the Decree of the Indonesian Minister of Health Number 1114 of 2005 on the Implementation Guidelines for Hospital Health Promotion, one of the efforts to improve patient health is hospital health promotion program. This program aims to enable patients, families, and community groups to prevent health problems, improve healthy measures more independently, and be active in the healing process, of course with supporting policy regulations. The implementation of hospital health promotion aims to make patients and families active in the healing process, disease prevention, and development of community-based health measures with supporting public policy regulations (Indonesian Ministry of Health, 2018). To achieve a balanced life, individuals must pay attention to various supporting aspects. One of the most important is the fulfillment of health needs. Various efforts i.e., promotive, preventive, curative, and rehabilitative ones are fairly needed to meet community health needs. However, curative and rehabilitative treatment is more dominant and followed by a healing process at public health facilities (hospitals or primary healthcare centers).

The second amendment of the 1945 Constitution Amendment in Article 28H of the Indonesian Constitution states that everyone has the right to live with physical and mental prosperity, to have a good and healthy living environment, and to obtain health services. In the the third amendment of the 1945 Constitution, Article 34 paragraph (3) states that the State is responsible for providing proper health services and public facilities. In accordance with the mandate of the 1945 Constitution, the government obligates to fulfill health facilities and services according to the community needs or public good. The fulfillment process requires support and actions from all aspects, especially health facilities, including hospitals that implement hospital health promotion (Olivia, 2010).

Health is a part of politics as the degree of health or health problems is determined by policies that could be directed or amenable by policy interventions. The hospital health promotion policy is also a political product. The program achievements are sensitive to the conditions of the existing political environment. Making a policy requires power and authority to foster cooperation and to resolve conflicts that might arise in the process of achieving the goals.

\section{METHODS}

The research method was literature review. Data were collected by literature study from various literature sources (books, theses, journals and others) concerning health politics and hospital health promotion both on an international and national scale; then, a qualitative analysis was carried out using thinking methods starting from general data to specific ones (Priasmoro, 2019). The results were analyzed systematically from March to May to facilitate reading about hospital roles in health promotion in the perspective of health politics.

\section{DISCUSSION Hospitals as Health Promoters}

One important element that supports the implementation of the National Health System (NHS) is health promotion approach. Optimal health development, according to the NHS, requires all society to participate to their best. Community 
empowerment is the effort possibly made for individuals, groups, and communities in the health sector in an integrated manner; integrated support in achieving the highest public health status by means of advocacy and monitoring can ensure its effective and targeted success (Indonesian Ministry of Health, 2018). The community empowerment may be in the form of health promotion aimed at encouraging people to make themselves and their environment healthy (Health Promotion Center of the Indonesian Ministry of Health, 2011).

The development of health promotion paradigm began in 1994, and it was firstly known as the Hospital Public Health Promotion (PKMRS). The term was changed to Hospital Health Promotion in 2003 (Department of Health, 2010). Hospital health promotion targets patients, families, and community groups in the surrounding environment. It is one of five PHBS as the flagship programs of health promotion. (Ayuningtyas, 2008). Hospital health promotion aims to enable patients, families, and community groups to prevent health problems, improve health more independently, and be active in the healing process. The hospital health promotion program is also considered very beneficial for hospitals if implemented optimally; it can improve the quality and image of hospital services.

In the process, hospitals should provide basic hospital health promotion guidelines on preparation, advocacy and socialization to stakeholders, training program for executors, monitoring as input for program development and improvement, and media broadcast (Nurdianna, 2017). There are strategic issues explaining why hospital health promotion has not run optimally. Firstly, it does not become a priority of health service policy at most hospitals. Secondly, the delivery of information regarding disease prevention and treatment is not clearly and continuously disseminated by health personnel to patients. Thirdly, a clean, healthy, and safe workplace has not been established by most hospitals. Finally, partnerships in promotive and preventive health services are still lacking.

The hospital health promotion program enables patients and families to understand types of diseases they suffer and their causes; this could allow them to understand its prevention (avoiding reinfection) and be active in the healing process. This promotional step is inseparable from the hospital health services (Nurdianna, 2017).

Hospital health promotion at some hospitals have been implemented for quite a long time, but the system and organization are not yet targeted in that the implementation is just based on interests and opportunities of certain health workers. The conditions are not fully supportive, and thus the pros and cons of various parties arise. On one hand, certain paries feel that the hospital health promotion can make things i.e., time and cost complicated. On the other hand, some people argue the optimal hospital health promotion may exist as long as managers and administrators have the will and understanding of the benefits. To run hospital health promotion accordingly, relevant parties must agree with concepts, have supporting policies, and have sufficient resources i.e., humans, funding, and technology (Hakim, 2012). Program implementation is closely related to policy and planning, both of which are an enabling factor for achieving objectives (Burke, 2012).

In general, there are many opportunities for hospitals to promote health, both indoors and outdoors. The Regulation of Indonesian Ministry of Health Number 11 of 2006 states that successful implementation of hospital health promotion (in terms of objectives, strategies, resources, and media) needs at least 1 person whose degree is Bachelor of Public Health. This person should be assigned to assist in the process and design strategies for implementing hospital health promotion. Additionally, personnel with 
Associate Degree who are interested and talented in health promotion is required to assist in empowerment, building the atmosphere, and advocacy (Purba, 2016).

Based on the strategic framework of "Health for All" in the Ottawa Charter on Health Promotion, the Ljubjana Charter on health service reform, and the Budapest Declaration on hospital health promotion, the role of hospitals as health promoters is first to promote human dignity, equality, solidarity, and professional ethics. They should be aware of the differences in needs, values, and cultures of different population groups. Second, they should be orienting to quality improvement, patient welfare, patient, employee relatives, and environmental protection, and potential development to become a learning organization. Third, they focus on health with a holistic approach that does not only emphasize curative efforts. Fourth, they should prioritize people who provide health services for patients and their relatives, facilitate the healing process, and contribute to patient empowerment. Fifth, they should use existing resources efficiently and effectively and allocate resources on the basis of contributing to health improvement. Sixth, they should build good rapport with stakeholders in the health service system and community (Jancey, 2017).

\section{Health Politics}

Health politics is a development effort of public health. Among the people, there are many fundamental questions, for example, 'why health is political?' because of disparities in the degree of public health which is not evenly distributed. As a result, efforts to achieve justice must be strived for and fulfilled (Bambra, 2005). Health is a part of politics because health policies determine the degree of health and may be directed or amenable by political policy interventions. Besides, health is a human right. Health politics is the science and art of striving for the degree of public health through a constitutional system adopted by a region or country in creating a healthy society (Sade, 2012). Power is needed in policymaking and guarantees the degree of public health.

Health Politics, based on fundamental rights, is a state policy in the health sector that stands for citizen's rights. As a result, political decision-making will greatly affect public health, which affects the community welfare (Siswanto, 2004). Currently, the mindset of political stakeholders is significantly different from the concept of public health experts. Tto achieve optimal implementation of targeted health development, it is necessary to align the concepts.

According to the mindset of public health experts, health is the major component that must be improved. They think sources of health problems come from neglecting maternal and child health, having disparities in the rich and poor populations, and poverty. Health politicians must have evidence-based policies which prioritize disease prevention handling. However, the political elites do not have the same mindset of health development. A popularity survey mentioned the basis for political decision-making is what appears fast in the eyes of constituents as a development priority. This could become a problem if both public health experts and political elites reluctantly understand each other, especially community welfare development. The illustration makes health a political problem (Olivia, 2009).

Medical technicality is no longer the only reason for the emergence of health problems since economic, social, and political conditions also contribute to it. Political commitment is needed to solve health problems although th problemsolving is never easy; political actors in health cannot convince other political elites about long-term health investment that is productive, not consumptive. Health practitioners cannot convey the benefits of health investment in supporting the nation's development to the political elite (Siswanto, 2004). 
Being a health political actor is indeed not easy because what moves is not only the hands and feet, but also the heart and mind; however, fighting for the welfare and health is everyone's right and obligation. In health politics application, all political actors unnecessarily become health workers or have a health education background. Politics is a complex system of its own; it starts from the process of determining to implementing goals with various activities across many sectors. The decision-making on the objectives of the political system involves the selection of several alternatives and setting of priority objectives. However, public policies should be made concerning the regulation and distribution (or allocation) of existing resources (Palutturi, 2013).

Fostering cooperation may resolve conflicts during this process. Networking as well as participation in decision-making require authority and power. Therefore, stakeholders must convince the target either with coercion or not. A little coercion will make a strong impetus allowing policy issuance (Palutturi, 2013). Political practices often appear in everyday life, such as in economic, social, cultural, or other aspects. Politics does not only include individual interests but also prioritizes common interests (Palutturi, 2015).

\section{The Role of Hospital Health Promotion in Health Politics}

Hospitals as health promoters can participate in implementing health promotion supported by a preventive paradigm. Currently, the ingrained paradigm of society is still oriented towards disease treatment, which may trigger the society to think about the importance of health. Different preventive paradigm from an early age may increase the life expectancy. A strategy taken to achieve a better quality of life is improving a healthy lifestyle, consuming healthy food sources, relaxing physically and spiritually, increasing the body's ability to be more independent, as well as having capacities to fight for chronic diseases and even deaths. In short, all of these strategies may increase the quality of life (O. Greoene, 2006). The Indonesian Law No. 44 of 2009 concerning Hospitals states that a hospital is a health service institution that provides complete health services, including preventive, promotive, curative, and rehabilitative services. Therefore, each hospital must put efforts to improve health through various hospital health promotion activities as stated in the Regulation of the Indonesian Ministry of Health No. 4 of 2012.

Promotional and preventive strategies are carried out to achieve equality of affordable health services but still prioritizing quality, justice, and evidencebased work; moreover, fostering national and global partnerships is required to increasing community empowerment. The strategies consider the National Priorities in the Health Sector (PNBK) (Indonesian Ministry of Health, 2015). The WHO stated that an applicable health system must be integrated with existing health facilities i.e., hospitals through hospital health promotion program (WHO-Europe, 2004).

The hospital health promotion as preventive services for patients requires policy with its implementation accordingly. For example, hospitals may need to recruit more health workers or personnel in implementing preventive and curative programs. It supports to achieve public welfare thorougly without exception. In addition to that aspect, hospitals need to increase the level of health status for all parties (Pramesti, 2015).

Health development policies include (1) fostering partnerships and a cross-sectoral atmosphere; (2) increasing community independence and cooperation with the private sector; (3) improving the level of environmental health; (4) increasing resources in the health sector; (5) improving health efforts, (6) health development policy and management, (7) community protection from the illegal use of pharmaceutical goods, food, and medical 
devices, and (8) health science and technology (Ayuningtyas, 2008).

Evidence showed that the strongest health determinants in the modern era are social, cultural, and economic factors. These factors are considered by governments and international bodies. However, health inequality continues to exist in a country; for example, there are differences in socio-economic class, gender, and ethnic groups. There are still disparities in prosperity, welfare, and resources (Donkn et al, 2002).

The government obgligates to improve the community welfare by fulfilling the socio-economic needs. Besides, the government is responsible for creating an environment that is physically and spiritually healthy; the need for community welfare holds the same importance as social and economic factors in health determinants (Marmot and Wilkinson, 2001). By empowering the community to willingly create a healthy and ideal environment, their productivity may increase and, in turn, raise the quality of life. The government has done efforts to make the community prosperous as evidenced by various regulations and laws that spark diverse systems of community life, regarding physical, mental, and social aspects. Many burdens borne by the government may hinder execution and achievement. One example is health care costs. Encouraging the government to partner with the private sector, for both non-profit and profit organizations, in decision-making will share the burden.

Policy implementation is influenced by the extent to which the interests of the target group(s) are put into the policy (Razak, 2012). It could be illustrated that the implementation of health promotion may be carried out properly if supported by the government policies and hospital management. It is recommended that hospital health promotion standards should be included in hospital accreditation indicators. Due to increasing numbers of hospitals implementing hospital health promotion, more people are expected to change their health paradigm. In relation to the massive participation, health promotion policy is required immediately to improve service quality (Nurdianna, 2017). Support from all parties contributes to changes in attitudes, behavior, and a healthy environment everywhere. That way, the community can become independent and improve the degree of health by preventing and developing health businesses. To achieve a prosperous society, it is necessary to cooperate with each other in support of government healthcare policies.

Any types of policies carry the risk of failure. Likewise, implementing health development poses challenges that are not easy. Many undesirable things may occur; one example is struggling to fight for the respective interests. At the level of organizational units, there must be different perspectives between researchers and divisions in research-focused organizations. Second, the agency and other directorates general for resources may also have different interests. Third, between sectors, each party hold power to legitimize their interests (Firdaus, 2018).

Likewise, advocacy strategies in hospital health promotion aim to produce policies and regulations related to various aspects of the predetermined standards. In this case, how to interpret determinants of resources in the area of national development matters. Stakeholders who have the ability to convince decisionmakers will get what they want and vice versa. Parties who are unable to convince decision-makers must accept defeat in the struggle for meanings and resources.

Causes and predisposing factors for health and diseases that are better understood greatly affect the degree of public health (Bambra et al., 2005). Hospital health promotion is prominent in overcoming this issue. Giving care at its best allow hospitals to help patient recovery and improve the quality of patient life. To maintain it, patients and relatives must be prepared and educated more intensively 
through hospital rules and policies that have long-term impacts on improving the quality of life. Organizations produce, collect, and disseminate a great deal of knowledge which may impact local health structures and professional practice elsewhere.

Building collaboration in the planning and development stages determines what information is needed and ensures the final product relevancy and usefulness. Despite providing information, hospitals need to build cooperation and provide accurate information for actions. Knowledge should be viewed as an output of collaborative and problem-solving work between researchers and decision makers. It may produce reciprocal learning through planning, production, and dissemination. Hospital health promotion is considered relatively successful in this process when receiving recognition from the health bureaucracy and politicians. There are many opportunities for hospitals to further address health promotion process and its other aspects.

\section{CONCLUSION}

Hospital health promotion holds a big role in health politics mainly to improve the quality of life. It can be developed by preparing guidelines, advocacy and socialization to patients, clients, and community. Hospitals are expected to enable patients, families, and community to prevent health problems, improve health more independently, and be active in the healing process, supported by policy regulations. Advocating strategies of hospital health promotion is done by formulating policies and regulations related to various aspects of hospital health promotion in accordance to predetermined standards. The program also may overcome various prevention issues, for example, helping patient recovery and improving the quality of patient life.

Future research is expected to further analyze this topic more specifically and study the impact of the hospital health promotion on health politics.

\section{REFERENCES}

Ayuningtyas, D. (2008). Politik Pembangunan dan Kebijakan Privatisasi Pelayanan Kesehatan. Jurnal Manajemen Pelayanan Kesehatan, 11(02), 72-79. https://doi.org/https://doi.org/10.97 74/jmk.13.1.61-75.

Afshari A. et al. Health Promoting Hospitals: a Study on Educational Hospitals of Isfahan, Iran. Health Promotion Perspectives; 2016;6(1): 23.

Blendon. Robert J. (2009). Commentary: Understanding the Underlying Politics of Health Care Policy Decision Making.

Burke, Ketie, Kate Morris, Leona McGarrgle. 2012. An Introductory Guide to Implementation.

Dedi Afandi, Hak Atas Kesehatan Dalam Perspektif HAM, Jurnal Ilmu Kedokteran Jilid 2 Nomor 1, Jakarta.

Freeman, R. (2000). The Politics Of Health In Europe. Manchester. University of Manchester Press.

Green, L.W., \& Kreuter, M.W. 2000.Commentary on The Emerging Guide to Community Preventive Services from a Health Promotion Perspective. American Journal of Preventive Medicine, 18 (1), 7-9.

Gumilang B. \& Wulandari R. D. Policy Implementation Planning of Health Promotion in Universitas Airlangga Hospital. Jurnal Administrasi Kesehatan Indonesia. 2016;4(1):4856

Hadi, K. (2010). Satu Dasawarsa Relasi Politik Lokal dan Nasional Dalam Konteks Otonomi Daerah. Politika Jurnal Ilmu Politik, 1(2).

Hakim, L. (2012). Analisis Manajemen dan Intervensi Bagi Pasien Terhadap 
Upaya Promosi Kesehatan Rumah Sakit (PKRS) Di Rumah Sakit Umum Pusat Haji Adam Malik Medan Tahun 2012. USU Journal of Legal Studies, 1-10.

Health Promotion Center of the Indonesian Ministry of Health (2010). Standar Promosi Kesehatan Rumah Sakit. In Standar Promosi Kesehatan Rumah Sakit. Jakarta.

Indonesian Ministry of Health. (2015). RENSTRA KEMENKES 2015-2019. Jakarta.

Indonesian Ministry of Health. (2009). RPJPK 2005-2025 dan SKN. https://doi.org/10.1007/s13398014-0173-7.2

Indonesian Ministry of Health. (2018). PERMENKES RI No.44 Tahun 2018. In PMK 44 Tahun 2018.

Indonesian Ministry of Health Promotion Center. (2011). Standar Promosi Kesehatan Rumah Sakit. Jakarta.

Jancey, J. (2017). Health Promotion leads the way in " knowledge translation ': but just a newcoat? Health Promotion Journal of Australia, 2017, 28,89-90, 28, 89-90. https://doi.org/10.1071/HE13101

Kar S.S., Roy G., \& Lakshminarayanan, S. Health Promoting Hospital: A Noble Concept. National Journal of Community Medicine. 2012;3(3):558-562

Mardiansyah, R. (2018). Dinamika Politik Hukum Dalam Pemenuhan Hak Atas Kesehatan Di Indonesia. 4(1), 227. https://doi.org/10.25123/vej.2918

Masyrifah, 2015. Analisis Pemenuhan Standar Promosi Kesehatan di Rumah Sakit Islam Surabaya Tahun 2015. Skripsi. Surabaya: Universitas Airlangga.

Nurdianna, F. (2017). Pelaksanaan Promosi Kesehatan Di Rumah Sakit Universitas Airlangga Surabaya. Jurnal Promkes, 5(2), 217-231.

O. Greoene, E. (2006). Implementing health promotion in hospitals: Manual and self-assessment form (O. Greoene, Ed.). Diambil dari http://www.euro.who.int/document /E86220.pdf

Olivia, S. (2009). Politik Pembangunan dan Kebijakan Privatisasi Pelayanan Kesehatan. Jurnal Manajemen Pelayanan Kesehatan. https://doi.org/10.9774/jmk.13.1.61 $-75$

Olivia, S. (2010). Analisis Politik dan Kebijakan Pembiayaan Rumah Sakit Pemerintah DKI Jakarta. Jurnal Kesehatan Maysrakat Nasional, 5(3), 1-9.

Palutturi, S. (2013). Pentingnya Politik Bidang Kesehatan. Jurnal AKK, 2(3), 42-46.

Palutturi, S. (2015). Health Politics: Teori dan Praktek. Makassar.

Paul Hunt, The UN Special Rapporteur on The Right to Health: Key Objectives, Themes, and Intervention, Health and Human Right Vol 7 No.1, The President and Fellows of Harvard College.

Pramesti, N. (2015). Hubungan Dan Pengaruh Politik Terhadap Kesehatan Masyrakat. Jakarta.

Priasmoro, D. (2019). Literatur Riview: Aplikasi Model Sosial Dalam Pelayanan Kesehatan Jiwa Pada Ibu Hamil Dengan HIV/AIDS. Jurnal Ilmu Keperawatan (Journal of Nursing Science), 4(1), 12-19. https://doi.org/10.21776/ub.jik.201 6.004.01.2

Purba, A. (2016). Pelaksanaan Kegiatan Promosi Kesehatan Rumah Sakit (PKRS) di Rumah Sakit Bhayangkara Tingkat II Semarang. Jurnal Kesehatan Maysrakat Nasional, 4(4), 2356-3346.

Razak, A. (2012). Politik Kesehatan Gratis di Indonesia. Jurnal AKK, 1(1).

Sangkot, H. (2008). Manajemen Upaya Promosi Kesehatan Rumah Sakit (PKRS) Di Rumah Sakit Umum Pusat Nasional Dr.Cipto Mangunkusumo Jakarta Pusat 
Tahun 2008. Universitas Indonesia. Siswanto. (2004). Pendekatan Politik Sebagaii Strategi Dalam Advokasi Pembangunan Kesehatan. JMPK, 07(04), 1-57.

Siswanto. (2007). Politik Dalam Organisasi. Jurnal Manajemen Pelayanan Kesehatan, 10(4), 159165.

Tiraihati, Zelbi Windarini. 2017.Analisis Promosi Kesehatan Berdasarkan
Ottawa Charter RS Onkologi Surabaya. Jurnal Promkes.Vol 5, No.1, Juli 207;1-11.

Virginia A. Leary, The Right to Health in International Human Right Law, Health and Human Right Vol 1 No.1, The President and Fellows of Harvard College

WHO-Europe. (2004). Standards for Health Promotion in Hospitals. 